\title{
Aboriginal Ceramic Sherds from 41MA30 in the Navasota River Basin in Madison County, Texas
}

Timothy K. Perttula

Heritage Research Center, Stephen F. Austin State University

Follow this and additional works at: https://scholarworks.sfasu.edu/ita

Part of the American Material Culture Commons, Archaeological Anthropology Commons, Environmental Studies Commons, Other American Studies Commons, Other Arts and Humanities Commons, Other History of Art, Architecture, and Archaeology Commons, and the United States History Commons

Tell us how this article helped you.

This Article is brought to you for free and open access by the Center for Regional Heritage Research at SFA ScholarWorks. It has been accepted for inclusion in Index of Texas Archaeology: Open Access Gray Literature from the Lone Star State by an authorized editor of SFA ScholarWorks. For more information, please contact cdsscholarworks@sfasu.edu. 


\section{Aboriginal Ceramic Sherds from 41MA30 in the Navasota River Basin in Madison County, Texas}

\section{Creative Commons License}

\section{(c) (1) \&}

This work is licensed under a Creative Commons Attribution-NonCommercial 4.0 International License 


\title{
Aboriginal Ceramic Sherds from 41MA30 in the Navasota River Basin in Madison County, Texas
}

\author{
Timothy K. Perttula
}

\section{INTRODUCTION}

Aboriginal ceramic sherds from three sites (41MA27, 41MA29, and 4IMA30) in the Navasota River basin in the Prairie Savannah of Texas provided the opportunity to investigate their spatial and temporal nature, and to establish with a reasonable certainty their origins, ethnic affiliations, as well as relationships to other ceramic assemblages in the general region (Perttula 2012). A second collection of nine ceramic sherds is available from $4 \mathrm{IMA} 30$, and this article describes the analysis of these additional sherds, and then summarizes the character of the larger assemblage ( $n=30$ sherds) as a whole.

\section{METHODS OF SHERD ANALYSIS}

The analysis of the second collection of ceramic sherds from 41MA30 is based on differences in temper, type of sherd (i.e., rim, body, or base), rim and lip form (cf. Brown 1996:Figure 2-12), decoration (if present, including the identification of motifs and elements). surface treatment (smoothing, burnishing, or polishing; see Rice 1987), and firing conditions (cf. Teltser 1993). Temper is the deliberate and indeterminate materials found in the paste (Rice 1987:411), including a variety of tempers (grog or crushed sherds, burned bone, etc.). Sherd cross-sections were inspected macroscopically and with a 10X hand lens to determine the character of the paste and its inclusions. Determining the liring conditions was based on the identification of the firing core in the sherd cross-sections and the identification of oxidation patterns as defined in Teltser (1993:535-536 and Figure 2a-h). Finally, wall thickness was recorded in millimeters (mm), using a vernicr caliper, along the mid-section of the sherd.

\section{SECOND SHERD COLLECTION FROM 41MA30}

The second collection from the site includes nine body sherds (Table 1). Five are from plain sandy paste Goose Creek Plain, var. unspecified vessels (cf. Aten 1983; Aten and Bollich 2011), probably simple jars and bowls. Another sandy paste sherd has bone temper and is decorated with a series of horizontal and diagonal incised lines above a possible carination of a carinated bowl. The other three sherds have a silty to clayey paste, two with grog temper added to the paste, and the third sherd (from a relatively thin-walled bowl) having no temper. One of the grog-tempered sherds is from a jar with overlapping brushing marks on the exterior vessel surface. This latter sherd may be from a vessel obtained in trade/exchange with a neighboring Caddo group sometime after ca. A.D. 1250.

\section{SUMMARY OF THE CERAMIC ASSEMBLAGE FROM 41 MA30}

The ceramic assemblages from 4 I MA30 now includes 30 sherds (Table 2). Few of the sherds (10\%) have decorations, and most of the sherds are from vessels that have a sandy paste $(70 \%)$ and no temper inclusions. A few sandy paste sherds ( $10 \%$ ) have bone temper inclusions, $3.3 \%$ have no temper and a clayey-silty paste, while another $16.6 \%$ of the sherds are from vessels that have a silty or clayey paste with bone and/or grog fragments used as a temper in vessel manufacture. 
Table 1. Second collection of sherds from 41MA30.

\begin{tabular}{lllllll}
\hline Sherd type & Paste & Temper & ST & FC & $\begin{array}{l}\text { Thickness } \\
(\mathrm{mm})\end{array}$ & Decoration \\
\hline body & SP & - & I M & G & 8.6 & plain \\
body & SP & - & I & 7.0 & plain \\
body & SP & - & E SM & F & 8.6 & plain \\
body & SP & - & E SM & H & 5.9 & plain \\
body & Slain \\
body & SP & - & E SM & F & 7.3 & horizontal-diagonal \\
incised lines \\
body & sone & I/E & B & 8.8 & plain \\
silty- & grog & I/E B & G & 7.1 & overlapping brushed \\
clayey & $\begin{array}{l}\text { silty- } \\
\text { clayey } \\
\text { silty- }\end{array}$ & grog & I SM & G & 7.5 & plain \\
clayey & - & - & & F & 5.4 &
\end{tabular}

$\mathrm{SP}=$ sandy paste; $\mathrm{ST}=$ surface treatment; $\mathrm{I}=$ =interior: $\mathrm{E}=$ =xterior; $\mathrm{SM}=$ smoothed: $\mathrm{B}=$ =burnished: $\mathrm{FC}=$ firing condition; $\mathrm{B}=$ fired and cooled in low oxygen; $\mathrm{F}-\mathrm{H}=$ fired in a reducing environment and cooled in the open air

Table 2. Ceramic assemblage from 41MA30.

\begin{tabular}{llllllll}
\hline Site & $\begin{array}{l}\text { No. of } \\
\text { Sherds }\end{array}$ & No. Decorated & SP & b/SP $\begin{array}{c}\text { No } \\
\text { Temper }\end{array}$ & g & b-g \\
\hline 41 MA30 & 30 & 3 & 21 & 3 & 1 & 4 & 1 \\
Percentage & $10 \%$ & $70 \%$ & $10 \%$ & $3.3 \%$ & $13.3 \%$ & $3.3 \%$ \\
\hline
\end{tabular}

$\mathrm{SP}=$ sandy paste; $\mathrm{b}=$ bone-tempered: $\mathrm{g}=$ grog-tempered

The sherds from the $41 \mathrm{MA} 30$ ceramic assemblage include one plain grog-tempered bowl rim (direct rim and a rounded lip, $6.7 \mathrm{~mm}$ in thickness), with smoothed interior and exterior surfaces, 26 body sherds, and three base sherds. Approximately $80 \%$ of the $41 \mathrm{MA} 30$ sherds have a sandy paste, ranging from a fine to coarse paste. Three of the sandy paste sherds (either fine or coarse paste) also have bone temper inclusions. Four sherds have grog temper and a clayey or silty paste, and one clayey-silty paste body sherd has no temper. Finally, one body sherd with a clayey or silty paste has fine grog and bone temper inclusions. The sherds are from vessels fired predominantly in a low oxygen or reducing environment (83\%). Four other sherds (sandy paste only) are from incompletely oxidized vessels, and one is from a vessel that was fired and cooled in an oxidizing environment (sandy paste sherd). Of the reduced fired vessel sherds, the majority of them had been fired in a reducing environment but cooled in the open air, leaving thin lighter oxidised bands at one or both surfaces of the vessel core (ef. Teltser 1993:Figure 2f-h). Four of the bone-tempered, grog-tempered, or grog-bone-tempered sherds $(44 \%)$ are from vessels fired in this manner compared to $57 \%$ of the sandy paste sherds. The majority of the tempered vessels ivere fired and cooled in a low oxygen or reducing environment. 
The sherds are from moderately thick vessels, probably mostly jars and simple bowls. Sandy paste body sherds are $7.24 \pm 0.85 \mathrm{~mm}$ thick (range from $5.3-9.1 \mathrm{~mm}$ ), but there is considerable variability in vessel wall thickness within this ceramic group. Sandy paste base sherds are $10.8 \pm 0.93 \mathrm{~mm}$ in thickness. The bonesandy paste sherds are $7.25 \pm 0.35 \mathrm{~mm}$. The one grog-tempered rim is $6.7 \mathrm{~mm}$ in thickness. The grog and grog-bone-tempered body sherds range from $6.4-7.5 \mathrm{~mm}$ thick, with a mean thickness of $6.9 \pm 0.50 \mathrm{~mm}$. The sherds are from vessels that were regularly smoothed on either interior $(57 \%)$ and/or exterior $(43 \%)$ surfaces.

There are three decorated sherds from 41MA30. They include a jar body sherd (bone-tempered and fine sandy paste) with a single straight incised line that is adjacent to a tool punctated-filled zone (this zone may have been triangular in shape, with incised lines creating the triangle that was filled with punctations); a possible carinated bowl with a simple incised decoration on the rim panel; and a brushed body sherd.

\section{CONCLUSIONS}

$41 \mathrm{MA} 30$ has ceramic sherds that appear to be part of an aboriginal ceramic tradition localized in the east-central part of the state of Texas (see Perttula and Ellis 2013). This tradition is recognized by a preponderance of plain sandy paste pottery (Goose Creek Plain, var. unspecified), and this plain sandy paste pottery represents a distinctive aspect of the material culture remains of the inland Mossy Grove Culture defined by Story (1990:258 and Figure 39). These sites are found in the Brazos, Trinity, and Neches-Angelina river basins in Southeast, East central, and East Texas.

The earliest ceramics in the region were non-tempered and plain sandy paste jars and bowls with burnished and/or floated surfaces, most likely related to Goose Creek Plain and Bear Creek Plain sandy paste ceramics found on sites in inland and coastal settings in Southeast and East Texas. This kind of pottery has been made from as early as ca. 2000-2100 years ago (Perttula and Ellis 2013). Plain sandy paste bone-tempered wares in the region are documented as early as A.D. 70 in the Trinity River basin (Walker County) and by ca. A.D. 400 in the Navasota River basin (Grimes County). Eventually, after ca. A.D. 400, potters that made these sandy paste wares began to occasionally decorate them with incised and punctated design elements, or they applied a thin red wash or slip to one or both vessel surfaces. The majority of the sherds from 4IMA30 were very likely made and used locally in this ca. 600 year interval of the Woodland period.

More dramatic changes in the aboriginal ceramics in the region occurred after ca. A.D. $900 / 1000$, when vessels began to be made with grog, bone, and hematite temper mixtures. Vessels generally had a sandy paste, but in other instances, clayey or silty pastes were chosen for use in vessel manufacture, as with a few sherds from 41MA30. Different vessel forms came into use alongside jars and bowls of various sizes and volumes, including bottles and carinated bowls. At this same time, decorated grog, bone, and grog- and bone-tempered vessels from local sites had styles/decorative elements closely resembling Caddo pottery made in East Texas, as well as Southeast Texas coastal pottery (see Aten 1983).

The grog- and bone-tempered brushed sherd from $41 \mathrm{MA} 30$ represents a second and even later Late Prehistoric use, as well as evidence of the widespread distribution of prehistoric Caddo pottery in parts of the Post Oak Savanna. Much of the Caddo pottery found in Prairie Savanna sites was likely made in East Texas by Caddo potters, and the vessels were probably the product of periodic trade between Caddo and non-Caddo peoples. In certain circumstances, however, some of the Caddo pottery found in the region was probably made by Caddo peoples who at certain times in the past (particularly after ca. A.D. 1300/1400) established permanent settlements in parts of the Trinity and Navasota River basins. Engraved, brushed, incised, incised-punctated, and punctated sherds from grog-tempered, bone-tempered, and sandy paste sherds occur in Post Oak Savanna sites that date from between ca. A.D. 1200-1400. The brushed sherd in the 41MA30 collection would not be out of place in an assemblage of decorated and grog-tempered Caddo pottery found in East Texas (i.e., the Neches River basin) on sites dating after A.D. 1250. 


\section{ACKNOWLEDGMENTS}

I want to thank Bill Moore for the opportunity to analyze the second collection of prehistoric ceramic sherds from $41 \mathrm{MA} 30$.

\section{REFERENCES CITED}

Aten, L. E.

1983 Indians of the Upper Texas Coast. Academic Press, New York.

Aten, L. E. and C. N. Bollich

2011 Early Ceramic Sites of the Sabine Lake Area, Coastal Texas and Louisiana. Studies in Archeology 43. Texas Archeological Research Laboratory, The University of Texas at Austin.

Brown, J. A.

1996 The Spiro Ceremonial Center: The Archaeology of Arkunsas Valley Caddoan Culture in Eustern Oklahoma. 2 Vols. Memoirs No. 29. Museum of Anthropology, University of Michigan, Ann Arbor.

Perttula, 'T. K.

2012 Aboriginal Ceramic Sherds from Three Sites along the Navasota River in Madison County, Texas. La Tierra, in press.

Perttula, T. K. and L. W. Ellis

2013 Aboriginal Ceramics among Groups living in the Prairie Savanna Region of 'lexas. Bulletin of the' Texas Archeological Society 84, in press.

Rice, P. M.

1987 Pottery Analysis: A Sourcebook. University of Chicago Press, Chicago.

Story, D. A.

1990 Cultural History of the Native Americans. In The Archeology and Biourcheology of the Gulf Coastal Plain, Vol. l, by D. A. Story, J. A. Guy, B. A. Bumett, M. D. Freeman, J. C. Rose, D. G. Steele, B. W. Olive, and K. J. Reinhard, pp. 163-366. Research Series No. 38. Arkansas Archeological Survey, Fayetteville.

Teltser, P. A.

1993 An Analytic Strategy for Studying Assemblage-Scale Ceramic Variation: A Case Study from Southeast Missouri. American Antiquity 58(3):530-543. 